\title{
The impact of Covid-19 on the pediatric dentistry clinic: An integrative review
}

\author{
Bruna Eliza De Dea ${ }^{1}$, (D) Grasieli de Oliveira Ramos², (D) Lea Maria Franceschi Dallanora ${ }^{3}$, (D) Victor \\ Angelo Martins Montalli ${ }^{4}$, (D) Danilo Antônio Duarte ${ }^{5}$
}

\section{Highlights}

The COVID-19 pandemic change the dental care protocols, because dental office has a high risk of cross-infection for health professionals.
In pediatric dentistry, dental care has to be reduced to cases of urgency and emergency during the COVID-19 pandemic.
When the dental intervention in pediatric dentistry is necessary, noninvasive or minimally invasive techniques that reduce aerosols should be prioritized.
${ }^{1}$ Professor at Universidade do Oeste de Santa Catarina (UNOESC), 2125 Getulio $V$ argas St, zip code: 89600-000, Joaçaba, Santa Catarina, Brazil

2 Professor at Universidade do Oeste de Santa Catarina (UNOESC). 2125 Getulio Vargas St, rip code: 89600-000, Joaçaba, Santa Catarina, Brazil

${ }^{3}$ Professor at Universidade do Oeste de Santa Catarina (UNOESC). 2125 Getulio Vargas St, zip code: 89600-000, Joaçaba, Santa Catarina, Brazil

${ }^{4}$ Professor at São Leopoldo Mandic. 13 doctor José Rocha Junqueira St., Swift, zip code: 13045-755. Campinas, São Paulo, Brazil

${ }^{5}$ Professor at São Leopoldo Mandic. 13 doctor José Rocha Junqueira St., Swift, rip code: 13045-755. Campinas, São Paulo, Brazil

\section{Correspondence:}

Getulio Vargas St, zip code: 89600000, Joaçaba, Santa Catarina, Brazil. Telephone: +55 (49) 35512047.

E-mail address:

bruna.dedea@,unoesc.edu.br

Received: 22 October 2020

Accepted: 20 November 2020

Online First: 15 December 2020

\section{Abstract}

At the end of 2019, new cases of pneumonia of unknown etiology were identified in China, the cause was attributed to a new type of coronavirus, this infection quickly spread to other countries and gained pandemic status by World Health Organization (WHO) in March 2020. Therefore, containment measures were taken, including social isolation and pause in dental care, since the aerosols generated during this care are classified as high risk for contamination by COVID-19. In this context, children do not seem to be very affected by this infection, since the number of cases is low, but they are considered asymptomatic carriers, contributing to the transmission of the virus to other people. Therefore, the aim of this study was to review the literature in an integrative way, seeking to elucidate the impacts of these factors on the clinical practice of pediatric dentistry. The search resulted in 290 articles, of which 33 were selected for full reading, and 29 articles were included in the integrative review. The COVID-19 pandemic greatly changed the practice in dentistry, new biosafety protocols were established, aiming to minimize viral spread, in pediatric dentistry, dental care was reduced to cases of urgency and emergency, as children are asymptomatic carriers of viruses and when they manifest symptoms, they are less severe when compared to adults. Another recommendation is that whenever dental intervention in pediatric dentistry is necessary, non-invasive or minimally invasive techniques that reduce aerosols should be prioritized.

Keywords: Child; Containment of Biohazards; Coronavirus; Pediatric Dentist 


\section{INTRODUCTION}

In late 2019, a series of pneumonia events, of unknown etiology, were reported in the city of Wuhan, Hubei province, China. With the spread of new cases in other regions and countries, the cause has been attributed to a new type of coronavirus. In February 2020, this respiratory disease was named COVID-19, or "coronavirus disease 2019" by World Health Organization (WHO) 1, the new coronavirus being called SARS-CoV-2 by the International Virus Taxonomy Committee. In March 2020, WHO classified it as a pandemic, a public health emergency of international interest. ${ }^{2-4}$

In September 2020, the term syndemia is introduced for COVID-19. Syndemia "characterizes the mutually aggravating interaction between health problems in populations in their social and economic context". The biological interactions, linked to social and economic factors, have become important for the prognosis, treatment and development of health policies to control the spread of COVID-19.5

The new coronavirus belongs to the Coronaviridae family, being divided into alpha coronavirus and beta coronavirus (infecting the respiratory, gastrointestinal and central nervous systems of humans and mammals) and gammachoronavirus and betacoronavirus (mainly infecting birds). ${ }^{6}$ It is believed that the period of incubation period is approximately 5 to 6 days, ranging from 2 to $14 .^{2}$

The main means of transmission of this disease are droplets of saliva or nasal, oral and ocular secretions from asymptomatic or symptomatic individuals. ${ }^{4,6,7}$

Fever, cough, myalgia, kidney failure and acute respiratory disease stand out as signs and symptoms. In addition, anosmia and ageusia are considered prodomic signs. The clinical course is not yet fully understood, being heterogeneous between adults and children. While symptomatic adults can evolve to a severe condition, children are asymptomatic or mostly mild or moderate symptomatic. ${ }^{8-10}$

Considering the combination of the means of transmission of the disease, the absence of vaccine, the "very high" risk of contamination by the dentist, and of every child being considered asymptomatic carrier, the convenience of an integrative review on the impact of these factors is evident in the practice of pediatric dentistry.

\section{METHODS}

\section{Study design}

It is an integrative review, which is a study based on bibliographic productions, allowing a theoretical analysis of a subject, filling a knowledge gap, with consequent application of results in practice. Its application in the health area is relevant and has been widely used in order to recap the research available on specific subjects, reorienting practical attitudes. ${ }^{11}$

This research obeys the quality indicators for Integrative Review articles, being elaborated in the phases: definition of the guiding question; literature search; data collect; critical analysis of the included studies; discussion of results and presentation of the integrative review. ${ }^{11}$

\section{Search strategy}

The literature review was performed based on the active search for information in the PubMed, Scopus, Lilacs, Bireme, Scielo databases. The searches were performed by the author BEdeD; they were carried out in articles published until October 3, 2020, excluding those published after this date.

The search strategy for each database was developed using the AND and OR combination of free terms and $\mathrm{MeSH}$ terms. Terms related to COVID-19 infection ("new coronavirus", "Novel Coronavirus", "Nuevo Coronavirus", "Novo Coronavirus", "Coronavirus disease", "Enfermedad por Coronavirus", "severe acute respiratory syndrome coronavirus 2", "2019ncov", "ncov 2019”, "2019ncov", "covid19”, "COVID-19”, “covid2019”, "covid-2019”, “covid 2019”, “srag-cov-2", “sars-cov-2", “sars2”, “sars 2", “sars cov 2", “cov19”, “cov2019”, "Coronavirus*", "Severe Acute Respiratory Infections", "Severe Acute Respiratory Infection", "Coronavirus 2", "acute respiratory disease", "Betacoronavirus", "Coronavirus infections", 
"sars vírus", "Wuhan market vírus", "virus mercado Wuhan", "Wuhan Coronavirus", "Coronavirus de Wuhan)" AND "pediatric dentistry" were combined with each other in all database searches.

The intention of this integrative review is to locate, interpret and synthesize the volume of evidence produced in this pandemic period and incorporate it in the decisions of control, treatment and pediatric procedures.

\section{Article eligibility criteria}

The articles identified by the initial search strategy were selected according to the following inclusion criteria: articles whose themes referred to the management and dental care of pediatric patients, or which dealt with biosafety in dentistry during the COVID-19 pandemic; published until October 3, 2020, abstract and / or articles available online for full reading. Articles that did not answer the guiding question; published as of October 4, 2020, abstracts and / or articles that were not available online for reading in full and duplicate articles in the databases were excluded.

\section{Selection of publications and data extraction}

The titles resulting from the search in all databases were arranged in a Microsoft Excel® spreadsheet so that repeated titles could be verified; reading the titles and excluding those that did not fit the inclusion criteria, the resulting abstracts were read in sequence and, subsequently, the preselected articles were read in full to determine the review sample.

The selection was made by the author BEdeD1, under the supervision of the author $\mathrm{DD}^{2}$, the articles were chosen by consensus.

The data tabulated and presented in a table support the construction of the biosafety protocol and care for infant patients ".

\section{RESULTS}

The search in the databases resulted in 277 articles and 13 more from other sources, with 290 articles pre-selected. After removing duplicates (52) and reading the titles and abstracts, 33 articles were selected for full reading, of which 29 articles were included in the integrative review, 209 studies were excluded because they did not fit the study subject (Figure 1).

All of the 29 selected articles were published in the year 2020, the majority being published in the months of April, May and June. Most of the selected articles were published in English, only two were published in Spanish, one in Portuguese and one in Chinese (Table 1). Most of the selected articles are letters to the editor, editorials, and literature reviews, this shows the scarcity of publications on the topic. The guiding question of the research seeks to emphasize the influence of the pandemic in the clinical practice of pediatric dentistry, as well as to evaluate and synthesize protocols implemented in the post-pandemic.

Figure 1 . Search strategy and selection of articles

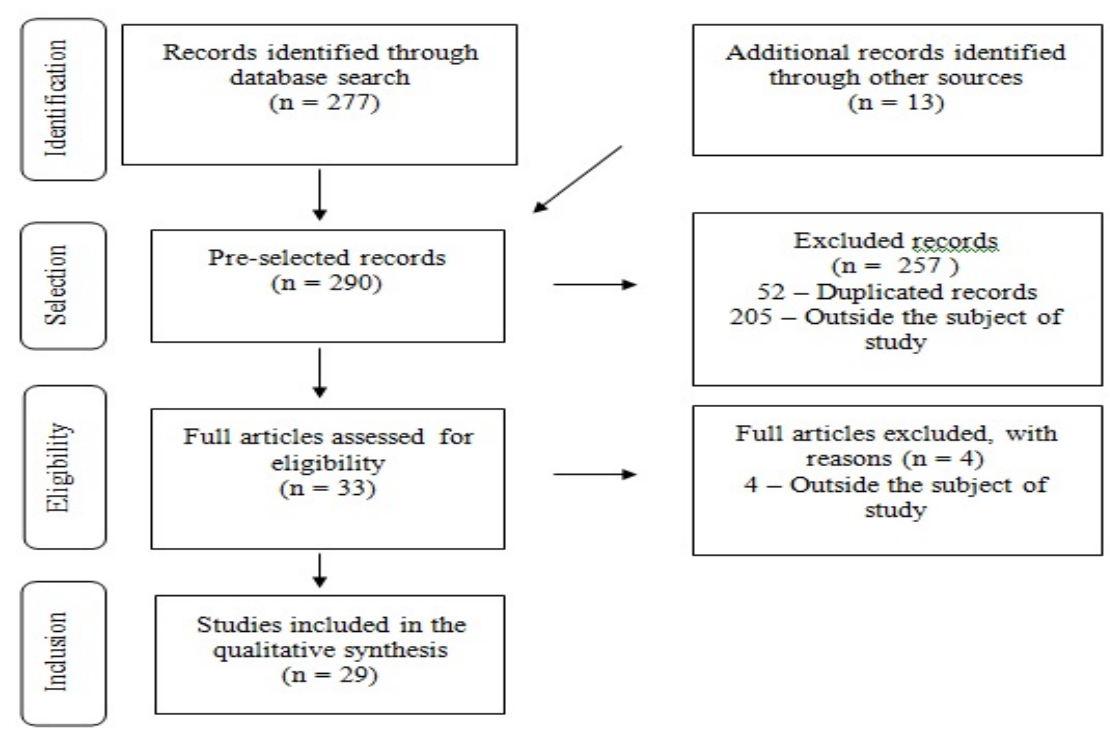


Table 1. Selected articles

\begin{tabular}{|c|c|c|c|c|c|}
\hline Author & Title & Main subject studied & Magazine & Language & Month/Year \\
\hline $\begin{array}{l}\text { Jayaraman, et } \\
\text { al. } 17\end{array}$ & $\begin{array}{l}\text { Impact of COVID-19 on Pediatric Dental Practice in the } \\
\text { United States }\end{array}$ & Guidelines on care in pediatric dentistry & Pediatric dentistry & English & May/20 \\
\hline LAAPD $* 16$ & $\begin{array}{l}\text { Ruta de atención para procedimientos de Odontología } \\
\text { Pediátrica urante la etapa de confinamiento o cuarentena } \\
\text { de la pandemia COVID-19 }\end{array}$ & Guidelines on care in pediatric dentistry & $\begin{array}{l}\text { Revista de } \\
\text { Odontopediatría } \\
\text { Latinoamericana }\end{array}$ & Spanish & April/20 \\
\hline $\begin{array}{l}\text { Ferrazzano, et } \\
\text { al., }{ }^{6}\end{array}$ & $\begin{array}{l}\text { COVID-19 Disease in Children: What Dentists Should } \\
\text { Know and Do to Prevent Viral Spread. The Italian Point } \\
\text { of View }\end{array}$ & $\begin{array}{l}\text { Guidelines on care in pediatric dentistry, } \\
\text { symptoms in children }\end{array}$ & $\begin{array}{l}\text { International journal of } \\
\text { environmental research } \\
\text { and public health }\end{array}$ & English & April/20 \\
\hline $\begin{array}{l}\text { Al- Halabi et } \\
\text { al. }{ }^{7}\end{array}$ & $\begin{array}{l}\text { Assessment of paediatric dental guidelines and caries } \\
\text { management alternatives in the post COVID- } 19 \text { period. } \\
\text { A critical review and clinical recommendations }\end{array}$ & Guidelines on care in pediatric dentistry & $\begin{array}{l}\text { European Archives of } \\
\text { Paediatric Dentistry }\end{array}$ & English & April/20 \\
\hline $\begin{array}{l}\text { Mantovani et } \\
\text { al. }{ }^{8}\end{array}$ & $\begin{array}{l}\text { Coronavirus disease } 2019 \text { (COVID-19) in children } \\
\text { and/or adolescents: a meta-analysis }\end{array}$ & Symptoms observed in children & Pediatric research & English & June/20 \\
\hline Ilyas et al. ${ }^{19}$ & $\begin{array}{l}\text { COVID-19 pandemic: the first wave - an audit and } \\
\text { guidance for paediatric dentistry }\end{array}$ & Guidelines on care in pediatric dentistry & British Dental Journal & English & June /20 \\
\hline Carlotti, et al. ${ }^{14}$ & $\begin{array}{l}\text { COVID-19 Diagnostic and Management Protocol for } \\
\text { Pediatric Patients }\end{array}$ & $\begin{array}{l}\text { Symptoms observed in children and } \\
\text { therapeutic protocols }\end{array}$ & Clinics & English & $\operatorname{March} / 20$ \\
\hline Sun, et al. ${ }^{15}$ & $\begin{array}{l}\text { Clinical features of severe pediatric patients with } \\
\text { coronavirus disease } 2019 \text { in Wuhan: a single center's } \\
\text { observational study }\end{array}$ & Symptoms observed in children & $\begin{array}{l}\text { World Journal of } \\
\text { Pediatrics }\end{array}$ & English & $\mathrm{Feb} / 20$ \\
\hline $\mathrm{LAAPD} * 21$ & $\begin{array}{l}\text { Teleodontología: Aplicación a la Odontopediatría durante } \\
\text { la pandemia COVID-19 }\end{array}$ & Use of Teledentistry in pediatric dentistry & $\begin{array}{l}\text { Revista de } \\
\text { Odontopediatría } \\
\text { Latinoamericana }\end{array}$ & Spanish & May/20 \\
\hline Sahu et al. ${ }^{2}$ & $\begin{array}{l}\text { Coronavirus disease (COVID-19): Characteristics in } \\
\text { children and considerations for dentists providing their } \\
\text { care }\end{array}$ & $\begin{array}{l}\text { Guidelines on pediatric care and symptoms } \\
\text { found in children }\end{array}$ & $\begin{array}{l}\text { International journal of } \\
\text { paediatric dentistry }\end{array}$ & English & April/20 \\
\hline Dong, et al. ${ }^{12}$ & $\begin{array}{l}\text { Epidemiology of COVID-19 Among } \\
\text { Children in China }\end{array}$ & $\begin{array}{l}\text { Clinical characteristics in children and } \\
\text { epidemiological aspects }\end{array}$ & Pediatrics & English & June/20 \\
\hline Peditto et al. ${ }^{4}$ & $\begin{array}{l}\text { Dentistry during the COVID-19 Epidemic: An Italian } \\
\text { Workflow for the Management of Dental Practice }\end{array}$ & Guidelines on care in pediatric dentistry & $\begin{array}{l}\text { International journal of } \\
\text { environmental research } \\
\text { and public health }\end{array}$ & English & May/20 \\
\hline $\begin{array}{l}\text { Casamassimo, } \\
\text { et al. }{ }^{22}\end{array}$ & Pediatric Dentistry During and After COVID-19 & Guidelines on care in pediatric dentistry & Pediatric dentistry & English & April/20 \\
\hline LAAPD $* 23$ & $\begin{array}{l}\text { Tratamento da doença cárie em época de COVID-19: } \\
\text { Protocolos clínicos para controle dos aerossóis. }\end{array}$ & Guidelines on care in pediatric dentistry & $\begin{array}{l}\text { Revista de } \\
\text { Odontopediatría }\end{array}$ & Portuguese & April /20 \\
\hline
\end{tabular}


Table 1. Selected articles (continued)

\begin{tabular}{|c|c|c|c|c|c|}
\hline Author & Title & Main subject studied & Magazine & Language & Month/Year \\
\hline Lu, et al., ${ }^{9}$ & SARS-CoV-2 Infection in Children & Symptoms observed in children & $\begin{array}{l}\text { The new England Journal } \\
\text { of medicine }\end{array}$ & English & April /20 \\
\hline $\begin{array}{l}\text { Martins-Júnior, } \\
\text { et al., }\end{array}$ & $\begin{array}{l}\text { Implications for dental professionals when caring for } \\
\text { paediatric patients }\end{array}$ & Guidelines on care in pediatric dentistry & Evidence-Based Dentistry & English & June/20 \\
\hline Pecoraro, et al, ${ }^{27}$ & $\begin{array}{l}\text { The psychophysical impact that COVID-19 has on children } \\
\text { must not be underestimated }\end{array}$ & $\begin{array}{l}\text { Psychological impacts on children post social } \\
\text { isolation }\end{array}$ & Acta Paediatrica & English & May/20 \\
\hline Wang, et al., ${ }^{31}$ & $\begin{array}{l}\text { Oral health management of children during the epidemic } \\
\text { period of coronavirus disease } 2019\end{array}$ & Guidelines on care in pediatric dentistry & $\begin{array}{l}\text { Sichuan Da Xue Xue Bao } \\
\text { Yi Xue Ban }\end{array}$ & Chinese & March/20 \\
\hline Amorin, et al., ${ }^{24}$ & $\begin{array}{l}\text { New Post-COVID-19 Biosafety Protocols in Pediatric } \\
\text { Dentistry }\end{array}$ & $\begin{array}{l}\text { Biosafety protocols in pediatric dentistry after } \\
\text { COVID-19 }\end{array}$ & $\begin{array}{l}\text { Pesquisa Brasileira em } \\
\text { Odontopediatria e Clínica } \\
\text { Integrada }\end{array}$ & English & June $/ 20$ \\
\hline Sun, et al., ${ }^{3}$ & $\begin{array}{l}\text { Knowledge of and attitudes toward COVID-19 among } \\
\text { parents of child dental patients during the outbreak }\end{array}$ & $\begin{array}{l}\text { Parental knowledge level during the social } \\
\text { isolation of the COVID-19 pandemic }\end{array}$ & Braz. Oral Res. & English & May/20 \\
\hline Brodim , P11 & Why is COVID-19 so mild in children? & Symptoms observed in children & Acta Paediatrica & English & April /2020 \\
\hline $\begin{array}{l}\text { BaniHani, A., et } \\
\text { al, }{ }^{33}\end{array}$ & $\begin{array}{l}\text { Could COVID-19 change the way we manage caries in } \\
\text { primary teeth? Current implications on Paediatric Dentistry }\end{array}$ & Guidelines on care in pediatric dentistry & Int J Paediatr Dent & English & June/2020 \\
\hline $\begin{array}{l}\text { Acharya S. et } \\
\mathrm{al},{ }^{25}\end{array}$ & $\begin{array}{l}\text { How to deal and learn from the threat of COVID-19 in } \\
\text { paediatric dentistry }\end{array}$ & Guidelines on care in pediatric dentistry & Eur J Paediatr Dent & English & September/2020 \\
\hline Saleha Shah ${ }^{26}$ & $\begin{array}{l}\text { COVID-19 and paediatric dentistry- traversing the challenges. } \\
\text { A narrative review }\end{array}$ & Guidelines on care in pediatric dentistry & $\begin{array}{l}\text { Annals of Medicine and } \\
\text { Surgery }\end{array}$ & English & October $/ 2020$ \\
\hline $\begin{array}{l}\text { Dellagiulia A. et } \\
\text { al, }{ }^{28}\end{array}$ & $\begin{array}{l}\text { Early impact of COVID-19 lockdown on children sleep: a } \\
\text { four-week longitudinal study }\end{array}$ & $\begin{array}{l}\text { Impact of social isolation by COVID-19 on } \\
\text { children's sleep. }\end{array}$ & J Clin Sleep Med & English & September $/ 2020$ \\
\hline $\begin{array}{l}\text { Baptista, AS et } \\
\text { al, }{ }^{30}\end{array}$ & $\begin{array}{l}\text { Can children's oral hygiene and sleep routines be } \\
\text { compromised during the COVID-19 pandemic? }\end{array}$ & Guidelines on care in pediatric dentistry & Int $J$ of Paed Dent & English & September $/ 2020$ \\
\hline $\begin{array}{l}\text { Bahramian H. et } \\
\text { al., }{ }^{18}\end{array}$ & COVID-19 Considerations in Pediatric Dentistry & Guidelines on care in pediatric dentistry & $\begin{array}{l}\text { JDR Clinical \& } \\
\text { Translational Research }\end{array}$ & English & July/2020 \\
\hline $\begin{array}{l}\text { Campagnaro R } \\
\text { et al, }{ }^{29}\end{array}$ & $\begin{array}{l}\text { COVID- } 19 \text { pandemic and pediatric dentistry: Fear, eating } \\
\text { habits and parent's oral health perceptions }\end{array}$ & Guidelines on care in pediatric dentistry & Child Youth Serv Rev & English & November/2020 \\
\hline Cianetti S. et al, ${ }^{32}$ & $\begin{array}{l}\text { Model for Taking Care of Patients with Early Childhood } \\
\text { Caries during the SARS-Cov- } 2 \text { Pandemic }\end{array}$ & Guidelines on care in pediatric dentistry & $\begin{array}{l}\text { Int. J. Environ. Res. } \\
\text { Public Health }\end{array}$ & English & May/2020 \\
\hline
\end{tabular}

Key: * LAAPD = Latin American Association of Pediatric Dentistry 


\section{DISCUSSION}

The pandemic established by COVID-19 forced healthcare professionals to change their care. Dentistry has significantly changed the routine of clinical practice, in the context of private practice and public services.

However, the absence of official guidance from health agencies and agents, challenged a search for worldwide bibliography, in order to systematize guiding recommendations for a safe clinical practice for infant patients and their family nucleus, dental surgeon and staff involved in the care.

The discussion of this research is based on the identification, evaluation and synthesis of the elected articles, didactically presented in the following subtitles: Systemic signs and symptoms; Determinants of service needs; Care in procedures and procedures to be prioritized.

\section{Systemic signs and symptoms}

The signs and symptoms in children, when compared to adult individuals, appear to be less severe, with a better prognosis and a very low mortality rate. It is advocated that the child has an innate and more active immune response, fewer ACE-2 receptors and/or acquired cross-immunity from previous contact with other coronaviruses and enteroviruses. ${ }^{12}$ Add to that less base comorbidities and a weaker acute inflammatory response to the COVID-19.7,8,10,12-14

Fever and cough are common, and pharyngeal erythema, diarrhea, nasal congestion, dyspnoea, abdominal pain and skin rash may also be present. Polypnea, sputum, nausea, vomiting, headache, fatigue, constipation are exacerbations of signs and symptoms when COVID-19 is associated with comorbidities such as leukemia and hydronephrosis. ${ }^{7-10,14,15}$

Radiographically, unilateral or bilateral pneumonia can be seen with signs of peripheral opacity. In more critical situations, ground glass opacity, pleural effusion and "white lung type" changes are detected. 7,9,10,15,16

Hematological tests show normality or with a reduction in white blood cells, eventually presenting leukopenia and lymphocytopenia. Levels of C-reactive protein may be normal or elevated. In more severe situations, they may be accompanied by an increase in liver enzymes. ${ }^{10,15}$

\section{Determinants of service needs}

We must assume that all children and their parents and / or guardians are potentially carriers of the virus, increasing the risk of cross-infection for health professionals ${ }^{8,17,18}$, so it is important to determine when it is necessary to perform a child's face-to-face care. In this pandemic period, it is essential to define what is urgency and emergency in pediatric dentistry. ${ }^{17,19}$

By definition, emergency is any situation where the patient's life is at risk and needs immediate care, dental emergencies must be treated exclusively in a hospital environment, as urgency is the management of complications that require immediate treatment for pain relief and control of infection. ${ }^{17}$ Dental emergencies must be handled within an hour, whereas emergencies can be handled within the first 24 hours. ${ }^{4}$ In Table 2 , we present the main dental conditions that are characterized as emergencies and urgencies.

Table 2. Procedures classified as urgent and emergency in pediatric dentistry

\begin{tabular}{|c|c|}
\hline Emergency & Urgency \\
\hline Excessive bleeding ${ }^{4,8,17}$ & $\begin{array}{l}\text { Severe irreversible pulpitis }{ }^{4,17} \\
\text { Pericoronitis }{ }^{4,17}\end{array}$ \\
\hline $\begin{array}{l}\text { Facial cellulitis with intra and extra oral edema } \\
\text { that compromises the airways or deep planes } \\
4,8,17\end{array}$ & $\begin{array}{l}\text { Dentoalveolar abscess }{ }^{4,8,17} \\
\text { Painful dental fracture } \\
\text { Alveolite }^{4,8,17} \\
\text { Dental trauma with avulsion or dislocation }\end{array}$ \\
\hline $\begin{array}{l}\text { Dentofacial trauma that can compromise the } \\
\text { airways } 8,17\end{array}$ & $\begin{array}{l}\text { Bleeding, } \\
\text { Biopsy or dental preparation prior to medical procedures } \\
4,8,17\end{array}$ \\
\hline
\end{tabular}




\section{Standard Precautions during patient care}

The Latin American Association of Pediatric Dentists recommends that during the period of social isolation dental care should be performed only in patients with cases of emergency and urgency, postponing elective treatment. ${ }^{17}$

Even treating only cases of emergency and urgency, it is essential that some care is performed, the screening of these cases must be performed through remote care (Teledentistry) in order to identify the situations that require faceto-face care, and to manage the elective cases.
After identifying the cases that require dental care during this period, appropriate biosafety measures must be taken, in addition, the use of techniques that reduce the generation of aerosols should be prioritized, thus reducing the risk of cross-contamination by COVID-19. 4, 7, 8, 12, 15-24 In Figure 2 we present a suggested care protocol for pediatric pediatric patients in the period of social isolation due to COVID-19.

Figure 2. Suggested care protocol for pediatric patients in the period of social isolation due to Covid-19

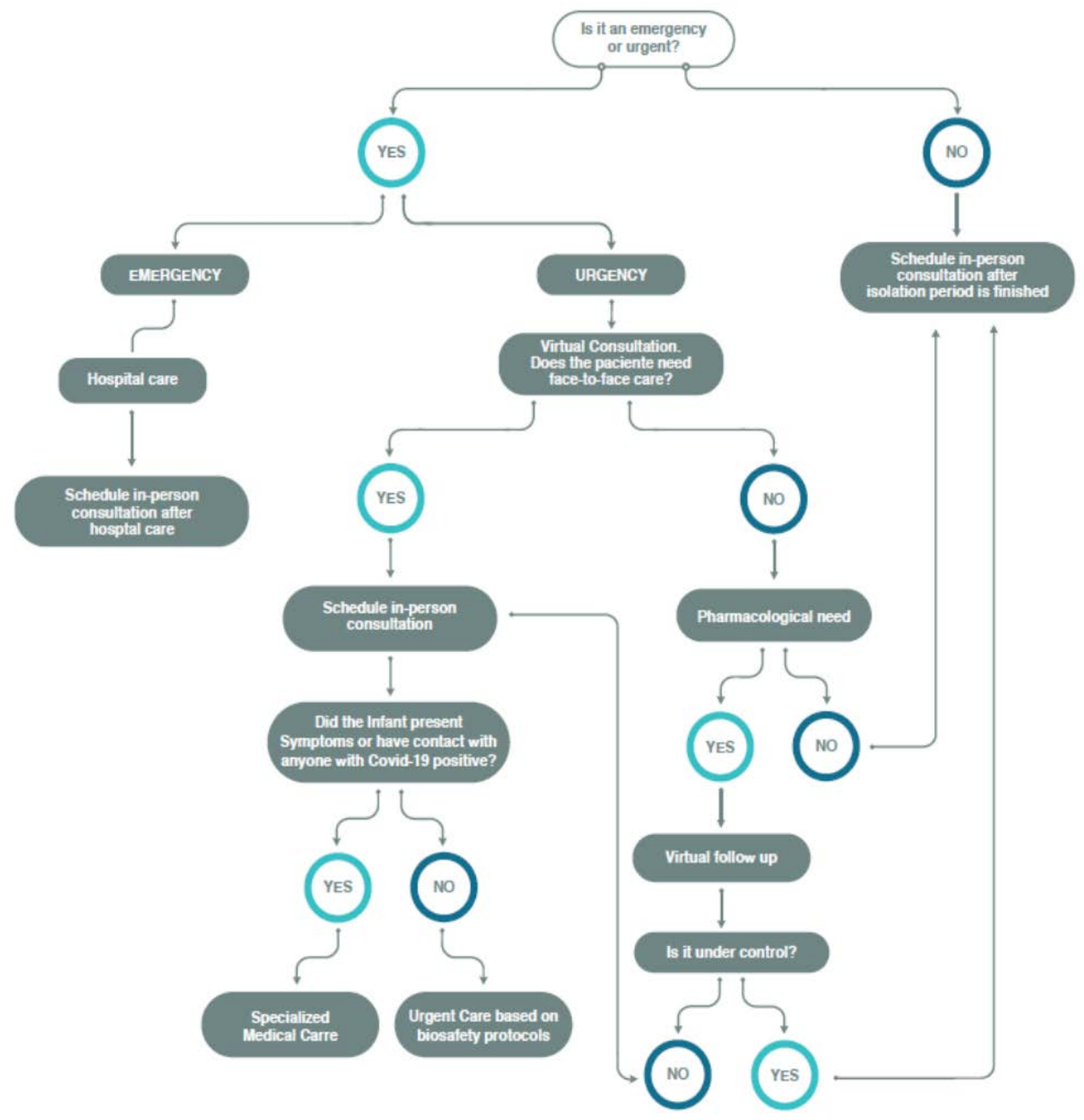




\section{Teledentistry in pediatric dentistry}

Teledentistry is an indispensable modification in care in the face of a public health crisis, especially when face-to-face contact between patient and health professional is not possible, due to geographic or sanitary restrictions. ${ }^{19}$ Teledentistry can be implemented through telephone resources, platforms tools and digital means that allow diagnosis, therapeutic guidance, patient control, in addition to defining the need or not for face-to-face care. ${ }^{12,17,25}$

Three types of teleconsultations are defined: asynchronous consultation, generally used when the patient or caregiver seeks the professional to consult their point of view, requires a waiting time between sending the question or request and the specialist's response; synchronous consultation, when the virtual consultation is in real time through telephone calls or preferably by video conference; mixed query is when using both synchronous and asynchronous queries. ${ }^{22}$

When conducting screening using this model, it is important to ask about signs and symptoms, pain and its characteristics, the presence of edema and fever. In situations of facial trauma, affected structures, active bleeding and involved teeth are investigated. The request for images assists in defining the need or not for face-to-face assistance. ${ }^{17,22}$

It is recommended that the virtual consultation is preceded by a questionnaire and the communication, like a face-to-face consultation, should be administered safely, with a soft and calm voice, in order to convey confidence to the patient. The clarification to the patient and / or caregiver regarding the benefits and limitations of this type of consultation must be emphasized. ${ }^{22}$

The virtual consultation allows anamnestic recording, however, as there is no possibility of the physical-clinical examination, a presumptive diagnosis is made and, if necessary, therapeutic recommendations. Particularly in pediatric dentistry, therapeutic recommendations must obey the concepts of pharmacological prescriptions, providing textual guidance to parents or guardians. ${ }^{22}$
It is necessary to emphasize that if the virtual consultation indicates the need for face-to-face assistance, this must be authorized with the signature of the Informed Consent Form by the family nucleus and evidently respect all biosafety rules. $^{22}$

\section{Biosafety in pediatric dentistry in times of COVID-19 pandemic}

The literature presents experiences in pediatric dentistry, where it was possible to diagnose caries lesions and make treatment decisions by means of intraoral cameras or images obtained through smart phones with the support of dental or personal assistants. The high transmissibility standard of COVID-19 can cause contamination in dentists and the dental environment favors cross-contamination. As a result, some biosafety protocols have been devised. In general, they encourage the avoidance of crowding, avoid the use of books / magazines, toys and plush toys in the waiting room, limit the number of daily appointments, use of masks for the patient and companion, disposable shoe protectors, hats, strict washing of clothes. hands. ${ }^{26,27}$

Regarding the professional using PPE and providing measures to reduce contamination: physical barriers in the clinical environment, cleaning and disinfecting surfaces / objects / environments with sanitizing products, goggles and face protectors, disposable aprons, respiratory masks with particulate filter, gloves and hats. Technically, aerosol-producing procedures should be avoided, and when produced, if possible, use physical barriers and / or dental aerosol vacuuming (high-power suction) and rubber dam. $4,17,18,25,26$

\section{Procedures to be prioritized}

The strategy recommended by WHO is the temporary suspension of elective procedures during the pandemic, which is controversial in relation to the recommendations of entities in the pediatric class. It is essential that each clinical situation is determined through its specificities and that associations of techniques can be performed during this period. Another important 
point to be considered is the psychological issue involved in this moment of isolation. ${ }^{17,28-31}$

Emotional disorders, depression, irritability, insomnia, stress, emotional exhaustion are examples of the symptoms reported in situations of quarantine and social isolation. These factors can influence the routine of eating, sleeping, oral hygiene and explain the difficulties that families have been facing due to the need for adaptations in this period. ${ }^{30,31}$

At the time of social isolation, where we do not yet have a vaccine and since dental care is considered to be at high risk of infection by COVID-19, we must prioritize urgent care and give preference to procedures that do not generate aerosols, especially minimally invasive, which are based on modern concepts for treatment and control of caries disease through a conservative approach. . $^{8,17-19,32,33}$

The emergency care services listed in Table 2, which require immediate treatment, must be performed following all the rules of the proposed biosafety protocols and the regulations defined by the health regulatory agency of each country.

In the treatment of caries disease, priority is given to techniques that do not generate aerosols, such as supervised tooth brushing, the use of low rotation, fluoride varnish, sealants, atraumatic restoration, selective removal of decayed dentin, application of silver fluoride diamine, non-control cavity restorer and hall technique.8,17,18,21,34

\section{Final Considerations}

Unquestionably the COVID-19 pandemic changed the behavior of the dental surgeon and their team, as well as the patient. This change is most strongly noticed in Pediatric Dentistry, given that the child alone, demonstrates a relative degree of anxiety in the face of medical and dental procedures. In addition, it always requires an escort. Social distancing itself has contributed negatively to the child's behavior, from a psychological point of view.

These factors associated with the risk of contamination by the new coronavirus in the dental environment, require strict compliance with biosafety rules and the care protocol, restricting the risks of contamination for the population and oral health professionals.

It is important to reinforce the strategies of dressing and de-dressing, waste disposal, surface disinfection and use of PPE.

We underline the importance of differentiating emergency and urgent interventions, and in mandatory face-to-face interventions, prioritize non-invasive or minimally invasive techniques that do not generate aerosols.

Considering that, still, we do not have consensus and strong scientific evidence on all measures and protocols, they are subject to change.

\section{REFERENCES}

1. World Health Organization. Coronavirus disease (covid-19) pandemic [Internet] [cited 10 Nov 2020]. Available from: https://www.who.int/es/emergencies/diseases/n ovel-coronavirus-2019

2. Sahu KS, Mishra AK, Lal A. Covid-2019: update on epidemiology, disease spread and management. Monaldi Arch Chest Dis 2020;90:197-205

3. Sun J, Xu Y, Qu Q, Luo W. Knowledge of and attitudes toward Covid-19 among parents of child dental patients during the outbreak. Braz Oral Res 2020;34:e066

4. Peditto M, Scapellato S, Marcianò A, Costa P, Oteri G. Dentistry during the Covid-19 Epidemic: An Italian Workflow for the Management of Dental Practice. Int J Environ Res Public Health 2020;17:3325-3339

5. Lemke MK, Apostolopoulos Y, Sönmez S. A novel COVID-19 based truck driver syndemic? Implications for public health, safety, and vital supply chains. Am J Ind Med 2020;63:659-662

6. Fini MB. What dentists need to know about Covid-19. Oral Oncol 2020;28:104741

7. Ferrazzano GF, Ingenito A, Cantile T. Covid19 Disease in Children: What Dentists Should Know and Do to Prevent Viral Spread: The Italian Point of View. Int J Environ Res Public Health 2020;17:3642-3648 
8. Al- Halabi M, Salami A, Alnuaimi E, Kowash M, Hussein I. Assessment of paediatric dental guidelines and caries management alternatives in the post Covid-19 period. A critical review and clinical recommendations. Eur Arch Paediatr Dent 2020;21:543-556

9. Mantovani A, Rinaldi E, Zusi C, Beatrice G, Saccomani MD, Dalbeni A. Coronavirus disease 2019 (COVID-19) in children and/or adolescents: a meta-analysis. Pediatr Res 2020 Jun 17. Doi: https://doi.org/10.1038/s41390-020-1015-2

10. Lu X, Zhang L, Du H, Shen K, Zhang J, Li $\mathrm{Y}$, et al. SARS-CoV-2 Infection in Children. The N Eng J Med 2020;382:1663-1665

11. Reis JG, Martins F, Lopes MH. Indicativos de qualidade para artigos de Revisão Integrativa. Tech Rep 2015;2020:220-228

12. Brodim P. Why is Covid-19 so mild in children? Acta Paediatr 2020;109:1082-1083

13. Dong Y, Mo X, Hu Y, Qi X, Jiang F, Jiang Z, et al. Epidemiology of Covid-19 Among Children in China. Pediatrics 2020;145:e20200702

14. Mallineni SK, Raggio DP, Araujo MP, Robertson MD, Jayakumar Jayaraman. Coronavirus disease (COVID-19): Characteristics in children and considerations for dentists providing their care. Int $\mathrm{J}$ Paediatr Dent 2020;30:245-250

15. Carlotti APCP, Carvalho WB, Johnston C, Rodriguez IS, Delgado AF. Covid-19 Diagnostic and Management Protocol for Pediatric Patients. Clinics 2020;75:e1894

16. Sun D, Li H, Lu XX, Xiao H, Ren J, Zhang FR et al. Clinical features of severe pediatric patients with coronavirus disease 2019 in Wuhan: a single center's observational study. World J Pediatr 2020;16:251-259

17.Asociación Latinoamericana de Odontopediatría. Grupo Covid-19. Ruta de atención para procedimientos de Odontología Pediatrica durante la etapa de confinamiento o cuarentena de la pandemia COVID-19. Rev Odontopediatr Latinoam 2020;10:1-10

18. Jayaraman J, Dhar V, Moorani Z, Donly K, Tinanoff N, Mitchell S et al. Impact of COVID19 on Pediatric Dental Practice in the United States. Pediatr Dent 2020;42:180-183
19. Bahramian $\mathrm{H}$, Gharib $\mathrm{B}$, Baghalian A. COVID-19 Considerations in Pediatric Dentistry. JDR Clin Trans Res 2020;5:307-311

20. Ilayas N, Agel M, Mitchell J, Sood S. Covid-19 pandemic: the first wave - an audit and guidance for paediatric dentistry. Br Dent J 2020;228:927931

21. Martins-Júnior PA, Coutinho DCO, Paiva SM. Implications for dental professionals when caring for paediatric patients. Evid Based Dent 2020;21:54-55

22.Asociación Latinoamericana de Odontopediatría. Teleodontología: Aplicación a la Odontopediatria durante la pandemia COVID-19. Rev Odontopediatr Latinoama 2020;10:11-19

23. Casamassimo PS, Townsend JA, Litch S. Pediatric Dentistry During and After covid-19. Pediatr Dent 2020;42:87-90

24. Asociación Latinoamericana de Odontopediatría. Tratamiento de la enfermedad de caries en época de covid-19: protocolos clínicos para el control de aerosoles. Rev Odontopediatr Latinoama 2020;10:20-25

25. Amorim LM, Maske TT, Ferreira SH, Santos RB, Feldens CA, Kramer PF. New post-Covid-19 biosafety protocols in pediatric dentistry. Pesqui Bras Odontopediatria Clin Integr 2020;20:e0117 26. Acharya S, Singh B, Godhi B, Godhi B, Pandey $\mathrm{S}$. How to deal and learn from the threat of COVID-19 in paediatric dentistry. Eur J Paediatr Dent 2020;21:173-175

27. Saleha S. COVID-19 and paediatric dentistrytraversing the challenges. A narrative review. Ann Med Surg 2020;58:22-33

28. Pecoraro L, Carbonare LD, De Franceschi L, Piacentini G, Pietrobelli A. The psychophysical impact that covid-19 has on children must not be underestimated. Acta Paediatr 2020;109:1679_ 1680

29. Dellagiulia A, Lionetti F, Fasolo M, Verderame C, Sperati A, Alessandri G. Early impact of Covid 19 lockdown on children sleep: a four-week longitudinal study. J Clin Sleep Med 2020;16:1639-1640 
30. Campagnaro R, Collet GdeO, Andrade MPde, Salles JPSL, Fracasso MLC, Scheffel DLS, et al. COVID-19 pandemic and pediatric dentistry: Fear, eating habits and parent's oral health perceptions. Child Youth Serv Rev 2020;118:105469

31. Baptista AS, Prado IM, Perazzo MF, Pinho T, Paiva SM, Pordeus IA, Serra-negra JM. Can children's oral hygiene and sleep routines be compromised during the COVID-19 pandemic? Int J Paediatr Dent 2020 Sep 25. Doi:10.1111/ipd.12732

32. Wang Y, Zhou C, Shu R, Zou J. Oral Health Management of Children during the Epidemic Period of Coronavirus Disease 2019. J Sichuan Union Univ Eng Sci Ed 2020;51:151154

33. Cianetti S, Pagano S, Nardone M, Lombardo G. Model for Taking Care of Patients with Early Childhood Caries during the SARS-Cov-2 Pandemic. Int J Environ Res Public Health 2020;17:3751-3760

34. BaniHani A, Gardener C, Raggio DP, Santamaría, RM, Albadri, S. Could COVID-19 change the way we manage caries in primary teeth? Current implications on Paediatric Dentistry. Int J Paediatr Dent 2020;30:523-525

\section{How to cite this article:}

Bruna Eliza De Dea, Grasieli de Oliveira Ramos, Lea Maria Franceschi Dallanora, Victor Angelo Martins Montalli and Danilo Antônio Duarte. The impact of Covid-19 on the pediatric dentistry clinic: An integrative review. Contemp Pediatr Dent 2020:1(1):2-12.

\section{Declarations}

Acknowledgements: Not applicable.

Conflict of Interest Statement: The authors disclose no potential conflicts of interest.

Ethics Statement: This study does not require approval from the ethics committee.

Informed Consent: Not required.

Author contributions: Conception and design: All Authors; Acquisition of data: GOR, LMFD, BEDD; Interpretation of data: GOD, BEDD; Drafting article: $V A M M, D A D, B E D D$; Revision artice: $V A M M$, $D A D, B E D D$; Final approval: All Authors

Funding: This work is not finantiated.

Data Availability: The data used to support the findings of this study can be made available upon request to the corresponding author.

Peer-review: Externally double-blinded peer-reviewed. 